Розвиток жіночої освіти в Криму (XIX - початок XX століття) : автореф. дис. на здобуття наукового ступеня канд. пед. наук : 13.00.01 / Т. В. Шушара. - Ялта : РИО КГУ, 2006. -20 с.

\title{
РОЗВИТОК ІМПЕРАТОРСЬКИХ УНІВЕРСИТЕТІВ ЯК СОЦІОКУЛЬТУРНИЙ ЧИННИК ЗАПОЧАТКУВАННЯ ВИЩОЇ ПЕДАГОГІЧНОЇ ОСВІТИ В УКРАЇНІ
}

Сомбаманія Г. М. Розвиток імператорських університетів як соціокультурний чинник започаткування вищої педагогічної освіти в Україні.

Стаття присвячена висвітленню особливостей становлення імператорських університетів як джерел започаткування вищої педагогічної освіти в Україні. Особлива увага приділяється аналізу організації теоретичної та практичної складових педагогічної підготовки випускників класичного університету.

Ключові слова: класичний університет, організація педагогічної підготовки викладачів.

Сомбамания А.Н. Развитие императорских университетов как социокультурный фактор возникновения высшего педагогического образования в Украине.

Статья посвящена обобщению особенностей императорских университетов как источников зарождения высшего педагогического образования в Украине. Особое внимание уделяется анализу организации теоретического и практического аспектов педагогической подготовки выпускников классического университета.

Ключевые слова: классический университет, организация педагогической подготовки преподавателей.

Sombamaniya H. N. Development of imperial universities as a sociocultural factor of establishing of higher pedagogical education in Ukraine.

The article is devoted to summarizing the features of imperatorskiy universities as sources of origin of higher pedagogical education in Ukraine. Special attention is paid to the analysis of the organization of the theoretical and practical aspects of pedagogical teacher training of the graduates of classical university.

Key words: classical university, organization of pedagogical teacher training.

Сучасні реформаційні процеси в університетській освіті загалом та в галузі підготовки наукових та науково-педагогічних кадрів зокрема умотивовані глобальними соціальноекономічними та суспільно-політичними змінами. Відповідно, вони потребують історикосистемного підходу до їх вивчення задля визначення подальших перспектив розвитку освітньої галузі. Отже, актуалізується спрямування - від сучасного до майбутнього через минуле. Особливої ваги у зв'язку з цим набуває дослідження періоду становлення вищої педагогічної освіти в Україні, коли освітніми реформами 1802-1804 pp. i 1828-1835 pp. було започатковано відкриття класичних «імператорських» університетів.

Розроблення означеної проблеми започаткували відомі історики, філософи та історики педагогіки XIX ст.: І. Альошинцев, Д. Багалєй, В. Бузескул, М. Гербель, М. Лавровський, Є. Ліхачова, С. Рождественський, М. Халанський, Є. Шмід та ін. Процес педагогічної підготовки вчителя визначеного періоду досліджувався О. Бутягіним, Є. Князєвим, М. Кузьміним, М. Нечаєвою, Ф. Паначиним, Л. Юрченко та ін. Питання філософії освіти, сучасного реформування педагогічної освіти піднято у працях А. Алексюка, І. Зязюна, В. Лутая, М. Михальченка, Л. Нечепоренко. Історію розвитку педагогічної освіти проаналізовано такими науковцями, як Л. Вовк, М. Свтух, О. Глузман, Н. Дем'яненко, В. Майборода, О. Сухомлинська, М. Ярмаченко та ін.

Ураховуючи актуальність означеної проблеми, метою статті є висвітлення 
особливостей становлення імператорських університетів як джерел започаткування вищої педагогічної освіти в Україні.

Як свідчить аналіз вітчизняної історії, український народ завжди прагнув до розвитку i піднесення освіти, культури й науки, через що у процесі становлення у вищих навчальних закладах України ідей започаткування педагогічної освіти правомірно виокремити події, які мали важливе значення. Так, переважна частина дослідників історії розвитку української освіти дотримується думки, що ідея організації педагогічної підготовки студентів бере свій початок з моменту діяльності їі перших вищих навчальних закладів Острозької академії (1576 р.) і Львівської братської школи (1585р.). Проте ії практична реалізація здійснюється значно пізніше завдяки активній науково-педагогічній діяльності Львівського (1661р.), Харківського (1805 р.), Київського (1834р.), Новоросійського (1865 р.) і Чернівецького (1875 р.) класичних університетів. С також думки науковців про те, що, по-перше, школи «вищого типу» функціонували ще за часів Київської Русі, через що першу вищу школу в Києві було засновано у 1037 р. у храмі Святої Софії, яка готувала педагогічні кадри зі складу «вищого духовенства і феодальної знаті». По-друге, першим вищим навчальним закладом на терені східного слов'янства була Києво-Могилянська академія (1632р.), у якій освіченість і провідні форми організації науково-дослідницької та науково-педагогічної роботи викладачів і студентської молоді, набравши сили у братських школах XVI-XVII століть при Віленському (1588 р.), Берестейському (1591р.), Мінському (1592 р.), Більському (1594 р.), Могилівському (1597 р.), Луцькому (1597 р.), Київському (1615 р.) братствах, розквітають, набуваючи більш зрілого вигляду [1, с. 3132].

Особлива роль у започаткуванні й розвитку системи педагогічної освіти належала КиєвоМогилянській академії, створеній у результаті об'єднання лаврської школи, заснованої напередодні митрополитом Петром Могилою, з братською школою, заснованою в 1615 p. I. Борецьким на Подолі. У результаті плідної науково-педагогічної діяльності відомих діячів культури, таких як Р. Заборовський, Г. Кониський, Ф. Прокопович, С. Яворський та ін., Києво-Могилянська академія набула ресурсу не тільки вогнища культурної «схизми» $\mathrm{i}$ літературного центру, а й освітньо-наукового інституту, який боровся проти полонізації в усіх сферах життя, зокрема духовній. Будучи елітною вищою школою, центром науки і культури козацької України, у Києво-Могилянській академії навчався і працював цвіт українського народу.

Натомість започаткування вищої педагогічної освіти в Україні загалом та практична реалізація цілеспрямованої системи відповідної загальнопедагогічної підготовки майбутніх викладачів нерозривно пов'язане зі становленням та розвитком класичних, зокрема імператорських університетів, оскільки вперше означене питання офіційно було порушено в освітній реформі 1802-1804 рр. Упродовж останньої в 1802 р. утворилося Міністерство народної освіти та визначився його основний підрозділ, на який, насамперед, покладалися обов'язки організації освіти - Головне правління училищ. У 1803 р. були затверджені «Попередні правила народної освіти», у 1804 р. - «Статут університетів Російської імперії» та «Статут навчальних закладів, підвідомчих університетам». Уся діяльність імператорських університетів визначалася статутними вимогами (1804 p., 1835 p., 1863 p. i 1884 р.).

Питання вищої педагогічної освіти на початку XIX ст. широко дискутувалося, оскільки мало місце два концептуальні підходи: 3 одного боку, більш поширеною була ідея післяуніверситетської педагогічної підготовки учителів та викладачів; 3 іншого висувалася інноваційна ідея поєднання професійно-педагогічної та предметно-наукової підготовки вчителя в умовах університетського навчання. Як наслідок, для підготовки педагогічних кадрів, згідно із загальним Статутом імператорських університетів 1804 р., передбачалося створення педагогічного інституту при кожному університеті [1]. Статут університетів передбачав окремий розділ «Про педагогічний інститут», де визначалися основні напрямки та зміст його роботи. «Педагогічний або вчительський інститут освічує 
вчителів для гімназій i училищ, що складають округ університету». Специфікою педінституту було те, що особлива увага приділялася формуванню у студентів уміння викладати. Задля цього розвивалося красномовство, здатність правильно i чітко висловлювати думки, логічно (усно і письмово) викладати матеріал. На утриманні в педагогічному інституті дозволялося мати 24 казеннокоштних студенти. На навчання в педінституті (як навчальному закладі інтернатного типу) зараховувалися особи після закінчення повного курсу університету. Педагогічну підготовку майбутні викладачі отримували протягом трьох (на університетських курсах - двох) років. По завершенню навчання вони зобов'язувалися відпрацювати на вчительській посаді не менше 6 років. Значна кількість випускників направлялася в школи, що зумовило започаткування вищої педагогічної освіти на базі університетів: педагогічні інститути (1811-1859 рp.) і педагогічні курси (1860-1867рр.). Це викликало до життя об'єктивну потребу в педагогічній підготовці, загальній для всіх майбутніх педагогів, незалежно від фаху.

Хронологічно першим вітчизняним класичним університетом уважається Львівський університет (1661р.) як значний науково-освітній центр. Утворений на базі Львівської єзуїтської колегії, у Львівському університеті спочатку діяло два відділи - філософський (підготовчий) та теологічний, викладання на яких здійснювалося латиною. Навчання в університеті за окремими рівнями завершувалося отриманням наукових ступенів ліценціата, бакалавра, магістра й доктора. 31784 р. крім філософського, юридичного, медичного і теологічного факультетів, до складу університету ввійшла й гімназія, що виконувала подвійну функцію: як база для комплектування контингенту студентів; як майданчик для педагогічної практики. 31787 р., моменту відкриття у Львівському університеті Руського (українського) інституту, уперше було порушено питання організації загальнопедагогічної підготовки студентів, оскільки мета його функціонування полягала в підготовці учителів для реальних училищ та гімназій, в яких навчалися українські діти. Згодом Львівський університет зробив відчутний внесок в педагогічну підготовку учителів шкіл та викладачів вищих навчальних закладів, оскільки його випускники (Я. Богословський, Я. Заблоцький, Ф. Лопатинський, М. Слотвинський та ін.) викладали у провідних навчальних закладах, зокрема у Московській академії, а наприкінці XVIII - середині XIX ст. було сформовано українську науково-педагогічну школу (M. Гриневецький, Я. Головацький, I. Лаврівський, П. Лодій, I. Мартинович, I. Могильницький та ін.).

Натомість перший педагогічний інститут на території України було відкрито в 1811 p. задля підготовки вчителів гімназій та училищ при Харківському університеті, заснованому в січні 1805 р. за ініціативою В. Каразіна - серекретаря Головного правління училищ народної освіти. Першим ректором цього вищого навчального закладу був доктор філософії, член Російської Академії наук І. Рижський, якому вдалося згуртувати навколо себе таких видатних науковців, як І. Тимківський, Т. Осиповський, І. Срезневський, Г. Успенський, І. Кронеберг [3]. Студенти чотирьох відділень (історико-філологічного, фізико-математичного, юридичного та медичного), окрім відвідування занять з лекційного курсу педагогіки повинні були пройти відповідну педагогічну практику: писати оповідання і твори, читати лекції, а також давати пробні уроки у середніх закладах освіти під керівництвом професора університету.

Оскільки з розвитком університетської педагогічної освіти тісно пов'язано становлення педагогіки як науки та навчальної дисципліни, то в 1807-1811 рр. педагогіку в Харківському університеті педагогіку викладав професор О. Рейніш у складі двох навчальних дисциплін - «Дидактики» i «Теорії виховання». В університетському педагогічному інституті курс теорії та історії педагогіки, а також методики викладання деяких предметів викладав директор - професор Х. Роммель, якому належать розробки та проведення педагогічного спецсемінару і практичних занять з педагогіки. У 1811-1812 pp. він видав навчальний посібник «План та правила навчання і викладання в педагогічному інституті», а також курс лекцій «Дидактика та методика». 31834 р. педагогіку викладав 
професор О. Валицький, який розробив «Програму-конспект курсу педагогіки», що впроваджувався в усіх вищих навчальних закладах того часу. У жовтні 1808 р. Радою університету була прийнята постанова про обов'язкове проходження майбутніми вчителями педагогічної практики у спеціально створених чи обладнаних навчальних закладах. Студенти, успішно виконавши завдання з педагогічної практики, претендували на здобуття вченого ступеня кандидата, що давало їм змогу посісти посаду старшого викладача. Якщо вони не вивчали педагогіки і не проходили педагогічної практики, то 3 1812 р. Рада університету прийняла рішення не присвоювати студентам вчені ступені [4]. Наприкінці XIX ст. в Харківському університеті вводяться спецкурси за педагогічними персоналіями, викладається «Загальний огляд педагогічних теорій XVIII-XIX ст.». У 1904 р. за розпорядженням Міністерства народної освіти педагогіка в університеті відновлюється як обов'язковий предмет для студентів історико-філологічного факультету. Поряд iз психолого-педагогічною, релігійною, філософською і прагматичною спрямованістю, у змісті загальнопедагогічної підготовки цього періоду починає утверджуватися професійна зумовленість.

Провідною метою функціонування педагогічного інституту (1835 р.) при Київському університеті Св. Володимира, заснованому на базі Волинського (Кременецького) ліцею в 1834 р., була підготовка вчителів для гімназій і повітових училищ. Першими ректорами університету, який спочатку діяв на підставі функціонування філософського, а згодом юридичного (1835р.) і медичного (1841 р.) факультетів, були видатні діячі освіти: історик i письменник Н. Максимович та історик В. Цих. Педагогічні дисципліни викладав професор С. Гогоцький у складі трьох навчальних курсів - «Наука про виховання», «Дидактика i прикладна педагогіка» та «Історія виховання». Окрім слухання університетських лекцій з педагогіки, студенти філософського факультету, який мав два відділення - історико-філологічне і фізико-математичне, а також юридичного (1835 р.) й медичного (1841р.) відділень, отримували керівництво у практичних педагогічних вправах за обраною кожним із них галуззю науки: писали «розсуди», проводили пробні лекції та давали уроки. Для кандидатів на учительські посади з числа тих, хто не навчався в університеті, але прагнув здобути вищу педагогічну освіту, Статутом університету 1835 р. [4] передбачалися спеціальні іспити.

Згідно з імператорським указом 1850 р. при Київському університеті Св. Володимира у 1852 р. було започатковано кафедру педагогіки. Навчальний курс «Педагогіка» зараховувався до обов'язкових екзаменаційних предметів на 2-3 курсах не тільки історикофілологічного, а також фізико-математичного й юридичного факультетів. Першим завідувачем кафедри педагогіки був М. Лавровський, який не тільки викладав «Дидактику», «Теорію виховання» «Історію педагогіки», окремі методики, а також зробив особистий внесок у розроблення проблеми змісту педагогічної освіти, організації педагогічної підготовки студентів класичного університету та методики викладання педагогічних дисциплін. Крім цього, училищні комітети (1804-1835рр.) сприяли вдосконаленню системи шкільної освіти відповідних навчальних округів через відкриття й опікування шкіл, методичної допомоги вчителям, видавництва підручників, навчальних посібників i забезпечення ними шкіл, створення шкільних бібліотек. Із середини XIX ст. сфера організаційно-педагогічної діяльності університету значно розширювалася, оскільки охоплювала також і екстернат (іспити позастаціонарним навчанням на звання домашнього вчителя) i післядипломну педагогічну підготовку освітянських кадрів через систему учительських з'їздів. Уведення в 90-х рp. ХІХ ст. нових навчальних курсів, зокрема експериментальної психології, техніки експериментальної педагогіки та практичних занять, викликали потребу проведення суто педагогічних досліджень, а також викладання педагогіки як незалежної від філософії навчальної дисципліни. На початку XX ст. на історико-філологічному факультеті Київського університету задля практичної підготовки майбутніх учителів діють історико-філологічна та психологічна семінарії. 
Серед імператорських університетів України почесне місце посідав Новоросійський університет, який було засновано в 1865 р. 3 ініціативи М. Пирогова, піклувальника Одеського навчального округу, на базі Рішельєвського ліцею, що функціонував в Одесі 3 1817 р. У кінці 20-х рр. ХІХ ст. при Рішельєвському ліцеї було відкрито педагогічне відділення з підготовки викладацьких кадрів передусім для цього закладу освіти зі складу найкращих його випускників, а пізніше й для повітових і комерційних шкіл. Педагогічне відділення спрямовувало свою діяльність на усвідомлення майбутніми викладачами сутності педагогіки як мистецтва виховання й навчання ліцеїстів. Директор Рішельєвського ліцею абат Ніколь уважав, що викладачі повинні передусім проникнутися «духом» цього навчального закладу через здобуття педагогічних знань, умінь і здібностей у процесі власної викладацької діяльності 3 ліцеїстами. Кафедру педагогіки в Рішельєвському ліцеї було засновано славетним Іваном Семеновичем Орлаєм (17701829 рр.), видатним діячем медицини, педагогіки й освіти, який 31826 року обіймав посаду директора Рішельєвського ліцею. М. Гоголь назвав І. Орлая незрівняним педагогом свого часу.

На початку академічного 1850-1851 р. було заборонено мирським професорам викладати філософські науки в університетах, педагогічних інститутах та Рішельєвському ліцеї. Викладання логіки, психології та інших наук доручено професорам Богословія та Законовчителям. У зв'язку з цим логіку, психологію та Моральне Богословіє для студентів усіх відділень читав професор Богословія і настоятель Ліцейської церкви Михайло Павлович Карповський за програмами, затвердженими Святішим Синодом. 31851 p. офіційно в Рішельєвському ліцеї знову було відтворено кафедру педагогіки під керівництвом Роберта Васильовича Орбинського, який закінчив курс наук в Головному Педагогічному Інституті зі званням Старшого вчителя. Професор Орбинський викладав курси дисциплін педагогічного циклу до і після реформування Рішельєвського ліцею в Новоросійський університет, у якому актуальні питання педагогіки досліджувалися зусиллями членів історико-філологічного факультету. Він також був першим викладачем психології та педагогіки на історико-філологічному факультеті новоствореного Новоросійського університету. У пам'яті колишніх студентів професор Орбинський залишився як найцікавіший лектор, що вміє найскладніше вчення викласти доступно i зрозуміло, а також як вимогливий екзаменатор. Особливий інтерес викликали його лекції 3 психології, що відвідувалися всім університетом. Завдяки йому значно поповнились фонди університетської бібліотеки спеціальною педагогічною літературою.

Новоросійський університет, продовжуючи славетні педагогічні традиції, відкрився у складі історико-філологічного (з відділеннями класичної, російсько-слов'янської філології та історичних наук), фізико-математичного (у складі відділів фізико-математичних, природничих наук, технічних наук 3 агрономією) та юридичного факультету. Передбачалося, що в Новоросійському університеті здобуватиме вищу наукову та педагогічну освіту молодь південних губерній України, Кавказу, а також слов'янських народів балканських країн. Новоросійський університет стає центром вищої освіти Півдня України завдяки діяльності багатьох видатних учених і педагогів: біолога I. Мечникова (ім'я І. Мечникова присвоєно університету в 1945 р.), фізіолога І. Сєченова, математиків О. Ляпунова, М. Чеботарьова, фізіолога В. Григоровича, фізика М. Умова, істориків Є. Щєпкіна, Ф. Успенського та ін.

Викладання педагогіки та психології в Новоросійському університеті було пов'язане 3 діяльністю видатних учених, що мали міжнародне визнання та авторитет. Так, у 18831886 рр. курс психології викладав Микола Якович Грот - відомий філософ і психолог, професор Новоросійського i Московського університетів. Особливістю викладання педагогіки у Новоросійському університеті в дореволюційний період було те, що вона базувалася на філософсько-етичному знанні.

У 1888 році в Новоросійський університет на посаду приват-доцента кафедри історії філософії було призначено Миколу Миколайовича Ланге (1858-1921рр.), завдяки 
науковим працям (започаткувавших новий напрям досліджень у психології експериментальний) та плідній організаційно-педагогічній діяльності якого Новоросійський університет стає всесвітньо відомим центром психолого-педагогічної науки, утримуючи цей статус впродовж тривалого часу. М. Ланге викладав більшу частину курсів, а саме: вступ до філософії, історію філософії, психологію, історію педагогіки, дидактику. Історію педагогіки й дидактику вчений викладав 3 власної ініціативи, бо надавав цим дисциплінам великого значення в системі гуманітарних наук. М. Ланге був чудовим лектором, послухати якого приходили не лише студенти, а й багато зацікавлених слухачів.

М. Ланге, видатний психолог, увійшов в історію педагогічної освіти як фундатор і перший директор Вищих педагогічних жіночих курсів в Одесі, вважаючи, що жінки мають право здобувати вищу освіту нарівні 3 чоловіками. Цим намірам вдалося здійснитися лише на початку ХХ ст. У рамках діяльності педагогічного відділу Історикофілологічного товариства М. Ланге порушив питання про реформу школи. Основні вимоги щодо іiі реформування були викладені в Доповідній записці, складеній від імені педагогічного відділу товариства і поданій Раді міністрів. У документі висувалися такі вимоги: обов'язковість початкового навчання й пов'язане з цим підвищення витрат на освіту принаймні до 6\% державного бюджету; загальна доступність державних шкіл безвідносно до стану, національності, віросповідання дітей; послаблення впливу держави на школу й посилення ролі громадських організацій; поширення прав педагогічних рад, надання їм права вибору підручників для навчання; усунення примусового характеру в релігійному вихованні; надання права земствам, громадським організаціям на відкриття шкіл зі своїми програмами. Висунуті М. Ланге вимоги до реформування освіти мали загальнодемократичний і гуманістичний характер, були спрямовані на лібералізацію відносин між державою та освітою завдяки зростанню впливу громадськості на школу, особливо на систему управління навчальними закладами.

У квітні 1921 р. на вакантну після смерті М. Ланге посаду професора кафедри філософії і психології вже наступника Новоросійського університету - Інституту народної освіти був обраний Сергій Леонідович Рубінштейн, який викладав курси психології, логіки і теорії пізнання, історії філософії. У другій половині $20-\mathrm{x}$ років у розробленні та розповсюдженні педагогічних ідей серед студентів університету значну роль відіграє педагогічний гурток на чолі з професором А. Готаловим-Готлібом. Він велику увагу приділяв питанням історії і теорії педагогіки, експериментальній психології, дидактиці та методиці викладання. 3-під його пера вийшло близько 200 праць.

Слід зазначити, що набір студентів до педагогічних інститутів імператорських університетів, які функціонували до 1859 р., не задовольняв потреб освіти того часу [3, c. 127]. Це змусило уряд у травні 1872 р. прийняти офіційне рішення про створення спеціальних - учительських інститутів для здійснення більш спеціалізованої професійної підготовки педагогічних кадрів [5, с. 147]. На цій підставі у класичних університетах тимчасово було невиправдано скорочено зміст і термін викладання педагогічних дисциплін, що негативно вплинуло на якість загальнопедагогічної підготовки випускників.

Криза системи педагогічної освіти у 1905-1916 pp., жорсткий міністерський контроль (бюрократизація мети та змісту освіти, насадження консервативних принципів організації навчального процесу, неоптимальність навчальних планів) у зв'язку 3 посиленням громадсько-педагогічного руху після революційних подій 1905 р. поступово змінюються тенденціями конструктивного характеру: стабілізацією загальнопедагогічної підготовки в навчально-виховному процесі закладів вищої освіти, наближенням до оптимального поєднання педагогічної теорії та шкільної практики, соціальною орієнтацією у формуванні особистості вчителя. Пошуки оптимальної моделі педінституту зумовлюють виникнення численних проектів організації підготовки вчителів, a, отже, i розроблення загальнопедагогічного іï компонента у різноманітності варіантів. Створюються концепції, 
розробляються варіативні проекти та моделі загальнопедагогічної підготовки вчителя (С. Ананьїн, Ф. Зеленогорський, В. Зеньківський, О. Музиченко, П. Тихомиров), зміст якої вибудовувався за наступними напрямами: філософсько-педагогічним (предмети педагогічного циклу читалися викладачами філософії, розглядалися як іiі складові); релігійно-педагогічним (предмети педагогічного спрямування затверджувалися Святим Синодом, знаходилися під впливом «основного» і «морального» богослов'я); психологопедагогічним (педагогічні дисципліни викладалися психологами, у тісному зв'язку й на основі психологічних знань); прагматично-педагогічним (у загальнопедагогічній підготовці вчителя переважав практичний компонент); педолого-експериментальним (акценти переносилися на особистість дитини, дослідно-експериментальне іiі вивчення); соціально зорієнтованим (у викладанні загальнопедагогічних дисциплін посилювався виховний аспект, зміцнювався зв'язок із соціумом); професійно зорієнтованим (загальнопедагогічна підготовка виокремилася в самостійний, стабільний напрям формування особистості вчителя). Перспективу подальшого дослідження становить організація науково-педагогічної освіти випускників магістратури.

\section{Література}

1. Важинський І. П. Становлення і розвиток педагогічної освіти в центральній та східній Україні (1802-1866 рр. ) / І. П. Важинський : Автореф. дис. ... канд. пед. наук : 13.00.01/ Полтавський державний педагогічний університет ім. В. Г. Короленка. - К., 2002. - 17 с. 2. Дем'яненко Н. М. Загальнопедагогічна підготовка на Київських вищих жіночих курсах (18781920 рр.) / Н.М. Дем'яненко // Педагогіка і психологія. - 1997. - № 4. - С. 211-216. 3. Коржов Д. Ю. Розвиток системи вищої освіти в Україні (кінець XIX-початок XX ст.) : навч. посіб / Д. Ю. Коржов. - Вінниця : ПП «Центр генеалогії і біографії», 1996. - 16 с. 4. Микитюк О. М. Університет як центр науково-дослідної роботи / О. М. Микитюк // Педагогіка та психологія. 2001. - № 18 ( 2 ). - С. 5-12. 5. Очерки истории школы и педагогической мысли народов СССР. Конец XIX - начало XX в. / Под ред. Э. Д. Днепрова, С. Ф. Егорова, Ф. Г. Паначина, Б. К. Тебиева. - М. : Педагогика, $1991-448$ с.

УДК 37.(091)

О. А. Устименко-Косорич,

докторант,

Луганський наиіональний університет імені Тараса Шевченка

\section{МУЗИЧНО-ПЕДАГОГІЧНИЙ ПРОФІЛЬ С. МОКРАНЬЦА В КОНТЕКСТІ РОЗВИТКУ МУЗИЧНОЇ ОСВІТИ СЕРБIї}

Устименко-Косоріч О. А. Музично-педагогічний профіль С. Мокраньца в контексті розвитку музичної освіти Сербії.

У статті визначено музично-педагогічний контекст творчості С. Мокраньца у процесі становлення сербської музичної освіти. Зазначені концептуальні музично-педагогічні ідеї діяча визначили шлях подальшого розвитку власної музичної школи Сербії. Розглянуто музично-освітні тенденції становлення музично-педагогічної школи Сербії в певній історико-культурній послідовності.

Ключові слова: музична освіта, музична школа, педагогічні ідеї, викладач, діяч, композитор, диригент, історико-культурна періодизація.

Устименко-Косорич Е. А. Музыкально-педагогический профиль С. Мокраньца в контексте развития музыкального образования Сербии.

В статье определен музыкально-педагогический контекст творчества С. Мокраньца в процессе становления сербской музыкального образования. Указанные концептуальные музыкальнопедагогические идеи деятеля определили путь дальнейшего развития музыкальной школы Сербии. Рассмотрены музыкально-образовательные тенденции становления музыкально-педагогической школы Сербии в определенной историко-культурной последовательности.

Ключевые слова: образование, музыкальная школа, педагогические идеи, преподаватель, 